\title{
Innovation and Entrepreneurship Education of Hebrew University and Its Enlightenment to China
}

\author{
Xinying Liu ${ }^{1, \mathrm{a}}$, Qishan $\mathrm{Mu}^{2, \mathrm{~b}}$ \\ ${ }^{I}$ Shandong University of Finance and Economic Center for Israel Studies Jinan, China \\ ${ }^{2}$ Shandong University of Finance and Economic Center for Israel Studies Jinan, China \\ asheila_guo1988@hotmail.com, ${ }^{b} 1693352612 @ q q . c o m$
}

\begin{abstract}
Innovation is the source of power for the continuous development of a country. Innovation and entrepreneurship are essential to economic development, and innovation and entrepreneurship education is the foundation for the development of innovation and entrepreneurship. Israel is a world-renowned country of innovation, and its emphasis on education ranks first. This paper studies the curriculum system, practical activities and service guarantees of the Hebrew University's innovation and entrepreneurship education ecosystem in Israel, and draws inspiration from China's innovation and entrepreneurship education reform. The first is to strengthen the construction of the innovation and entrepreneurship curriculum system, the second is to adjust the sources of innovation and entrepreneurship education teachers, the third is to actively carry out innovation and entrepreneurship experience exchange activities, and the fourth is to meet market demand and explore the direction of innovation.
\end{abstract}

Keywords: innovation and entrepreneurship ecosystem, components, curriculum system, enlightenment

\section{INTRODUCTION}

Israel lacks resources and has a harsh environment. The country has an area of only 22.1 square kilometers and a population of only about 9.2 million. In recent years, Israel's economy has developed rapidly, and per capita GDP has shown a rapid upward trend. In 2005, it exceeded $\$ 20,000$, in 2010 it exceeded $\$ 30,000$, and in 2017 it exceeded $\$ 40,000$. In 2020, Israel's per capita GDP reached $\$ 44,000$ and Israel became the country with the highest level of economic development in the Middle East.

The reason for the rapid development of Israel is, in the final analysis, its ability to innovate. Israel has a reputation as an "Start Up Nation". In January 2020, in the list of the world's most innovative countries released by Bloomberg, Israel ranked 6th, the top five were Germany, South Korea, Singapore, Switzerland and Sweden, and China ranked 15th. In terms of specific indicators, China ranks 2nd in patent activities and 5th in terms of higher education efficiency, but China's productivity and $R \& D$ personnel intensity ranks lower; while Israel ranks first in terms of $R \& D$ intensity and ranks No. 2 in terms of concentration of researchers.
Israel's achievements in innovation and entrepreneurship are the result of many factors, among which higher education is an important support. Israel's higher education has always taken the survival and development of the country as its own responsibility, and paid attention to the cultivation of college students' entrepreneurial awareness and entrepreneurial ability. As a world-class university in Israel, the Hebrew University has trained many outstanding talents for Israel and is the cradle of Israeli innovative ideas.

Innovation is the soul of a nation's progress and an inexhaustible driving force for the prosperity of a country. Innovation can promote the development of productive forces; it is essential to the development of a country. Entrepreneurship can not only relieve employment pressure, but also allow college students to do what they like and better realize their self-worth. Therefore, China has been vigorously encouraging innovation and entrepreneurship. In 2015, the General Office of the State Council of China issued the "Implementation Opinions on Deepening the Reform of Innovation and Entrepreneurship Education in Higher Education Institutions", proposing that deepening the reform of innovation and entrepreneurship education in higher education institutions is an important measure to 
comprehensively promote higher education reform and promote high-quality employment of graduates.

Israel's innovation and entrepreneurship ecosystem is leading the world. In order to improve the quality of my country's innovation and entrepreneurship education with high quality, it is necessary for us to learn relevant experience from Israel. Taking the Hebrew University as an example, this article analyzes the constituent elements of the innovation and entrepreneurship ecosystem of Israeli universities, sums up experience and draws inspiration, and provides valuable suggestions for China's innovation and entrepreneurship education reform.

\section{ELEMENTS OF THE HEBREW UNIVERSITY INNOVATION AND ENTREPRENEURSHIP EDUCATION ECOSYSTEM}

The innovation and entrepreneurship ecosystem refers to the direct interaction between the main organizations involved in innovation and entrepreneurship activities and between the main organizations and their environmental elements within a certain time and space, through the progress of science and technology, the expansion of economic benefits, and the diffusion of innovation awareness. The formation of specific interest structure and diversity of participating groups. The elements of the innovation and entrepreneurship education ecosystem of Hebrew University include: course teaching, practical activities and service guarantee.

\subsection{Course Teaching}

The teaching of innovation and entrepreneurship courses is not only the basic link of innovation and entrepreneurship education, but also the key link. Curriculum teaching enables students to be educated in the classroom learning process, master the basic knowledge of innovation and entrepreneurship, to a certain extent, develop students' innovative potential, expand students' thinking, and encourage students to innovate and start their own businesses. Hebrew University has formed two types of innovation and entrepreneurship curriculum systems: an internal curriculum system, mainly for the undergraduate and graduate students of Hebrew University; the other is an external curriculum system, mainly for social entrepreneurs, investors, innovators, etc. The internal and external curriculum system jointly drives the development of innovation and entrepreneurship education at the Hebrew University.

\subsubsection{Internal Curriculum System}

Table $I$ is the innovation and entrepreneurship courses at the Hebrew University. In the Hebrew University's internal curriculum system, School of Business Administration and Faculty of Social Sciences offer more innovation and entrepreneurship courses. The innovation and entrepreneurship courses of the Hebrew University include not only basic theoretical knowledge of innovation and entrepreneurship, but also professional-related innovation and entrepreneurship knowledge, taking full account of the needs of students' majors. The content of these courses is mainly to study the theories and paradigms of innovation and entrepreneurship in various fields. The main purpose is to enable students to master the basic knowledge and processes of innovation and entrepreneurship, at the same time to develop students' innovative thinking, develop students' entrepreneurial skills, and encourage students to start their own businesses.

TABLE I. THE INNOVATION AND ENTREPRENEURSHIP COURSES AT THE HEBREW UNIVERSITY

\begin{tabular}{|c|c|c|c|c|}
\hline Faculty & Department & $\begin{array}{l}\text { Course } \\
\text { Code }\end{array}$ & $\begin{array}{l}\text { Course } \\
\text { Name }\end{array}$ & Course/Module description \\
\hline $\begin{array}{l}\text { Rothberg } \\
\text { International } \\
\text { School }\end{array}$ & $\begin{array}{l}\text { Nonprofit } \\
\text { Management } \\
\text { \& Leadership }\end{array}$ & 01960 & $\begin{array}{l}\text { Strategic } \\
\text { Approaches } \\
\text { to Social } \\
\text { Innovation }\end{array}$ & $\begin{array}{l}\text { In this course we will study theories and paradigms of the } \\
\text { emerging field of social entrepreneurship. We will distinguish } \\
\text { between "social needs entrepreneurship" and "social vision } \\
\text { entrepreneurship" and draw on the literature of commercial } \\
\text { entrepreneurship to support this distinction. In addition we will } \\
\text { outline strategies of innovation which are prevalent in social } \\
\text { entrepreneurship. }\end{array}$ \\
\hline $\begin{array}{l}\text { Special } \\
\text { Programs }\end{array}$ & $\begin{array}{l}\text { Cornerstone } \\
\text { Program }\end{array}$ & 11160 & $\begin{array}{l}\text { Introduction } \\
\text { to Innovation } \\
\text { and } \\
\text { Entrepreneur } \\
\text { ship }\end{array}$ & $\begin{array}{l}\text { This course will allow participants to learn Innovation and } \\
\text { Entrepreneurship fundamentals and how they can help them } \\
\text { become more future proof in their careers. The course will focus } \\
\text { on how innovation can be developed and enhanced and then will } \\
\text { look at the world of entrepreneurship and how it can be relevant } \\
\text { for each and every one of the participants. }\end{array}$ \\
\hline $\begin{array}{l}\text { Faculty of } \\
\text { Humanities }\end{array}$ & $\begin{array}{l}\text { Melton } \\
\text { Blended } \\
\text { Masters In } \\
\text { Jewish } \\
\text { Education }\end{array}$ & 63014 & $\begin{array}{l}\text { Entrepreneur } \\
\text { ship and } \\
\text { Innovation in } \\
\text { Jewish } \\
\text { Education }\end{array}$ & $\begin{array}{l}\text { The course will focus on the foundation concepts of social } \\
\text { entrepreneurship and their application to Jewish education. In } \\
\text { addition strategies for growing the the market and of innovation } \\
\text { will be studied in depth. }\end{array}$ \\
\hline $\begin{array}{l}\text { School of } \\
\text { Business } \\
\text { Administration }\end{array}$ & $\begin{array}{l}\text { Business } \\
\text { Administration }\end{array}$ & 55691 & $\begin{array}{l}\text { Entrepreneur } \\
\text { ship in } \\
\text { FinTech }\end{array}$ & $\begin{array}{l}\text { Entrepreneurship in FinTech is a "real world" course in creating } \\
\text { and managing successful companies in the financial information } \\
\text { and technology sector. }\end{array}$ \\
\hline $\begin{array}{l}\text { School of } \\
\text { Business }\end{array}$ & $\begin{array}{l}\text { Business } \\
\text { Administration }\end{array}$ & 55721 & $\begin{array}{l}\text { Financial } \\
\text { Innovations }\end{array}$ & $\begin{array}{l}\text { Financial innovations give rise to new intermediaries, new types } \\
\text { of instruments, and new services, platforms or techniques to }\end{array}$ \\
\hline
\end{tabular}




\begin{tabular}{|l|l|l|l|l|}
\hline Administration & & $\begin{array}{l}\text { for Economic } \\
\text { Development }\end{array}$ & $\begin{array}{l}\text { create jobs, build communities, and enable capital formation and } \\
\text { economic growth. }\end{array}$ \\
\hline $\begin{array}{l}\text { School of } \\
\text { Business } \\
\text { Administration }\end{array}$ & $\begin{array}{l}\text { Business } \\
\text { Administration }\end{array}$ & 55820 & $\begin{array}{l}\text { Creativity and } \\
\text { Innovation in } \\
\text { Organizations }\end{array}$ & $\begin{array}{l}\text { This course takes the students to a journey through theories and } \\
\text { practices of innovation and creativity in organizations, } \\
\text { representing the dynamics and continuity of change, and defining } \\
\text { the capabilities and processes required. The course critically } \\
\text { reviews and integrates widespread and prominent approaches for } \\
\text { amplifying innovation and creativity in organizations. }\end{array}$ \\
\hline $\begin{array}{l}\text { School of } \\
\text { Business } \\
\text { Administration }\end{array}$ & Administration & 55541 & Finnovation & $\begin{array}{l}\text { Finnovation is a real-world course focusing on creating successful } \\
\text { FinTech startups. The course is structured as an Accelerator for } \\
\text { new ventures. Mixed teams of students from business, computer } \\
\text { science, and law disciplines will create an innovative financial } \\
\text { startups taking it through all steps of development. }\end{array}$ \\
\hline $\begin{array}{l}\text { School of } \\
\text { Business } \\
\text { Administration }\end{array}$ & $\begin{array}{l}\text { Business } \\
\text { Administration }\end{array}$ & 55680 & $\begin{array}{l}\text { Financial } \\
\text { Innovations - } \\
\text { Applied } \\
\text { Research }\end{array}$ & $\begin{array}{l}\text { In this Course we will survey the main fields of innovation that are } \\
\text { affected by regulations. In each of these fields we will review the } \\
\text { current innovative trends and the corresponding regulatory } \\
\text { regimes. }\end{array}$ \\
\hline $\begin{array}{l}\text { Faculty of } \\
\text { Social } \\
\text { Sciences }\end{array}$ & $\begin{array}{l}\text { Glocal } \\
\text { International } \\
\text { Development }\end{array}$ & 59525 & $\begin{array}{l}\text { Entrepreneur } \\
\text { ship and } \\
\text { Social } \\
\text { Innovation }\end{array}$ & $\begin{array}{l}\text { This course deal with the key concepts and of social } \\
\text { entrepreneurship. While a differentiation is made between this } \\
\text { field and commercial entrepreneurship, applicable paradigms from } \\
\text { the latter are studied. }\end{array}$ \\
\hline
\end{tabular}

Source: The author compiled according to the official website of the Hebrew University

\subsubsection{External Curriculum System}

In 1964, the Hebrew University founded the Yissum Research Development Company, a pioneer in the implementation of the Hebrew University's innovation and entrepreneurship education program, which protects the intellectual property rights of the Hebrew University, and markets the technology and scientific know-how generated by Hebrew University researchers and students. Yissum is 15 th in the world in the number of patents registered.

Recognizing the role of creativity and innovation in international competitiveness, Israeli universities have established innovation and entrepreneurship centers. The Hebrew University Center for Innovation and Entrepreneurship (ASPER HUJI-Innovate) was established with the support of the Israel Higher Education Commission to promote innovation and entrepreneurship of teachers and students of Hebrew University and promote the development of innovation and entrepreneurship education in Israel. The center operates on four parallel tracks-promoting entrepreneurial culture and communities, developing and running academic courses and programs, creating experience opportunities as hackathons and competitions, and managing accelerated programs for new businesses. These activities establish a point of contact between academia and the world of innovation and entrepreneurship.

In 2020-2021, ASPER HUJI-Innovate launched the Trans-disciplinary Innovation Program (TIP), OPEN Explore Project and OPEN 2021 Project. Tip invited students to spend their summer in the Israel and learn how to develop a startup at The Trans-disciplinary Innovation Program (TIP), which is an intensive 4-week international entrepreneurship program at ASPER-HUJI Innovate, the Hebrew University of Jerusalem's center for innovation and entrepreneurship. OPEN Explore
Project is a set of six short programs that help researchers and research students explore whether their ideas or technologies can be tranformed into viable business. The OPEN Explore Programs are the flagship startup acceleration programs. During the program period, founders were engaged in market research, ideation, business planning and product development. The programs offer hands-on workshops, support from experienced mentors, industry connections and a shared workspace. The programs culminate in a demo day event in which the founders market their startups to investors and other entrepreneurs.

The OPEN 2021 programs are designed to empower entrepreneurs in any field, and is suitable for people who have the motivation and drive required to start a business from scratch. Here start-ups can get up to $\$ 10,000$ in POC financing opportunities for financing and fundraising; understand the latest industry trends, conduct in-depth research on the market and customers, realize the development of business models and Prototype (MVP); conduct marketing and gain competition Advantage. Successful entrepreneurs can share their entrepreneurial experience through storytelling and public speeches.

These projects of the Hebrew University Innovation and Entrepreneurship Center have made important contributions to cultivating students' innovative and entrepreneurial spirit and supporting students' entrepreneurship.

\subsection{Practical Activity}

The Hebrew University not only pays attention to basic innovation and entrepreneurship classroom training for students, but also pays attention to the role of practical activities in enhancing students' innovation and entrepreneurship capabilities. Through various innovative and entrepreneurial practice activities, the school bridges the shortcomings of focusing on theory 
and ignoring practice in the teaching of innovation and entrepreneurship courses, and provides students with sufficient opportunities for practical exercises. The Hebrew University's innovative and entrepreneurial practices include various competitions and InnovNation Summer Program.

\subsubsection{Competitions}

Competition include Falling Walls Competition, The Morning After Competition and The Creativity Challenge Competition etc. Their innovation competitions allow students to experience entrepreneurship first-hand and examine the gap between idea and execution in a fast, creative and fun way. Every competition is adjudicated by industry and academic experts. Their innovation competition allows students to experience entrepreneurship firsthand and examine the gap between idea and execution in a creative and interesting way. Each game is judged by industry and academic experts. The competition encourages students to take planned risks, think creatively and improve their project management skills. For example, competitions require that complex projects be broken down into smaller parts, or teamwork or public speaking within a specified time. These competitions can experience the entrepreneurial process and test entrepreneurial ideas, not only without taking too much risk, but also to get feedback from experienced entrepreneurs.

Taking Falling Walls Competition as an example, the Falling Walls Lab is an international forum for the next generation of outstanding innovators and creative thinkers. Its aim is to promote outstanding ideas on a global scale and connect promising scientists and entrepreneurs from all fields. Participants have the opportunity to present their research work, business model or initiative to peers, a high-quality jury composed of academic and business experts, and the public in a 3minute speech. The competition is held in more than 90 locations around the world.

\subsubsection{InnovNation Summer Program}

The Hebrew University provides students, entrepreneurs and professionals with a behind-the-scenes opportunity to enter Israel's high-tech industry and entrepreneurial ecosystem, which is the InnovNation Summer Program. First of all, students or teachers who have entrepreneurial ideas through this program can meet leading startup founders, executives, angel investors and venture capital investors, technical experts and outstanding industry leaders. Secondly, successful startups, high-tech companies, multinational R\&D centers, business accelerators and research institutions can be accessed. Third, through this platform, you can learn practical models and tools for creating start-up companies and developing innovative companies. Fourth, the future of disruptive technologies can be explored here, such as 3D printing, nanotechnology, biomedicine, robotics, neuroscience, genetics, artificial intelligence, network computing, and so on.

\subsection{Service Guarantee}

The implementation of the innovation and entrepreneurship education plan needs a series of guarantees, including policy guarantee, financial guarantee, teacher team guarantee, technical guarantee, etc.

\subsubsection{Policy Guarantee}

Israel has adopted many supporting and encouraging policies for innovation, and every technological innovation in every industry has the opportunity to obtain government funding. The government has continuously improved the financial loan mechanism and provided preferential tax policies for innovative enterprises.

In 1985, Israel promulgated the "Industrial Innovation Promotion Law", which clarified the government's support for industrial innovation in legal form, and specified specific goals and implementation principles. As long as it conforms to the "science-based export-oriented" industrial orientation, it can be Apply for government scientific research funds. The law centralizes the formulation, implementation and coordination of innovation policies and other powers to the Chief Scientist Office under the Ministry of Economy. Under this legal framework, the Chief Scientist Office takes the lead in responsible for a series of R\&D support programs of the Israeli government.

In 2015, the Israeli government approved the establishment of the The Israel Innovation Authority (NATI for short). As an independent publicly funded agency, it was created to provide a variety of practical tools and funding platforms aimed at effectively addressing the dynamic and changing needs of the local and international innovation ecosystems. Its task is to explore whether anyone is interested in transforming the findings of researchers into products, to find research directions for the institute, so that they can develop innovative products according to the company's interests and needs, and promote the exchange of knowledge and experience.

\subsubsection{Financial Guarantee}

The Israeli government has always attached importance to education, especially higher education for training high-level talents, and has unswervingly implemented the development strategy of rejuvenating the country through science and education. Israel lists education funding as one of the three major government expenditures, and its expenditure is second only to the 
Ministry of Defense. Israel's education expenditures account for more than $10 \%$ of total expenditures in GDP, ranking first in the world. The Hebrew University's funding for higher education comes from three main sources. Government funding accounts for more than half, followed by student tuition, which accounts for about $1 / 5$, and the rest comes from donations and other channels.

\subsubsection{Teacher Team Guarantee}

The teachers engaged in the teaching of innovation and entrepreneurship courses at Hebrew University include both academic staff and part-time lecturers. Including Dr. Jonathan Mirvis, Dr. Amnon Dekel, Sharon Levite-Vaknin, Prof Glenn Yago, Dr. Sharon Arieli, Prof Dan Galai, Prof david gershon and Prof Zvi Wiener. All of these teachers have doctorate degrees, half of which are Professors. Among them, Dr. Jonathan Mirvis and Dr. Sharon Arieli are social entrepreneurs and business innovation experts, and they are part-time lecturers. Except for Ms. Sharon Levite-Vaknin, the other teachers are all elite teachers of the school, and these teachers have interdisciplinary backgrounds and experience in entrepreneurship or education management.

In addition to the innovation and entrepreneurship education classroom, the School of Humanities of the Hebrew University established The NCJW Research Institute for Innovation in Education, the School of Science established The Peter Brojde Center for Innovative Engineering and Computer Science, and the School of Business Administration established the Asper Center for Entrepreneurship and Real Estate and Entrepreneurship Center. These research centers have strong teachers and have laid a good foundation for the development of innovation and entrepreneurship education for Hebrew University students. Table II shows the composition of teachers in Innovation and Entrepreneurship Education at Hebrew University.

TABLE II. COMPOSITION OF TEACHERS IN INNOVATION AND ENTREPRENEURSHIP EDUCATION AT HEBREW UNIVERSITY

\begin{tabular}{|c|c|c|c|}
\hline \multirow{2}{*}{ Teacher composition } & \multicolumn{3}{|c|}{ Title } \\
\cline { 2 - 4 } & Dr. & Prof. & Other \\
\hline $\begin{array}{c}\text { Innovation and } \\
\text { Entrepreneurship Courses }\end{array}$ & $37.5 \%$ & $50 \%$ & $12.5 \%$ \\
\hline $\begin{array}{c}\text { The NCJW Research } \\
\text { Institute for Innovation in } \\
\text { Education }\end{array}$ & $43.3 \%$ & $37.8 \%$ & $18.9 \%$ \\
\hline $\begin{array}{c}\text { The Peter Brojde Center } \\
\text { for Innovative Engineering } \\
\text { and Computer Science }\end{array}$ & $62.5 \%$ & $37.5 \%$ & $0.0 \%$ \\
\hline $\begin{array}{c}\text { Asper Center for } \\
\text { Entrepreneurship }\end{array}$ & $75.0 \%$ & $25.0 \%$ & $0.0 \%$ \\
\hline $\begin{array}{c}\text { Real Estate and } \\
\text { Entrepreneurship Center }\end{array}$ & $42.9 \%$ & $57.1 \%$ & $0.0 \%$ \\
\hline
\end{tabular}

Source: The author compiled according to the official website of the Hebrew University

It can be seen that most of the teachers in the innovation and entrepreneurship education of Hebrew
University are doctors and professors with interdisciplinary education backgrounds. They are mainly engaged in innovative research in the fields of public policy management, psychological research, strategy and organizational behavior management, marketing, computer science and finance. At the same time, many of them are managers of colleges or departments, as well as investors and founders of companies. They have a certain social background and rich experience in innovation and entrepreneurship, and have certain capital absorption and venture capital capabilities.

\section{CONCLUSION AND ENLIGHTENMENT}

Through the analysis of the elements of innovation and entrepreneurship education in Hebrew University, Hebrew University has a relatively perfect curriculum system for innovation and entrepreneurship education, rich practical activities and certain service guarantee, which has greatly promoted the development of innovation and entrepreneurship education in Israel. China can learn from it.

First, strengthen the construction of the innovation and entrepreneurship curriculum system in colleges and universities. The Hebrew University's curriculum system is relatively complete, and an innovation and entrepreneurship research center has been established, which is of great significance for cultivating students' entrepreneurial awareness and improving students' innovation and entrepreneurship capabilities. Some universities in China offer a basic course of entrepreneurship at the undergraduate level, which is a general elective course. There are also some colleges and universities that only offer such courses in specific majors or colleges. For example, Peking University only offers the course of cultivating and experimenting the spirit of innovative entrepreneurs in the School of Economics. In addition to general elective courses, some schools will set up a professional-related innovation and entrepreneurship course in professional courses, such as creative economics, but very few schools offer such courses. Therefore, it is necessary to strengthen the construction of innovation and entrepreneurship curriculum system in colleges and universities, and set up more innovation and entrepreneurship courses, in order to stimulate students' interest in innovation and entrepreneurship and enhance their innovation and entrepreneurship capabilities.

Second, adjust the sources of teachers for innovation and entrepreneurship education. The Hebrew University not only has many professors or PhDs in innovation and entrepreneurship courses for undergraduates and graduate students, but also hires professional social entrepreneurs and business innovation experts to teach. The teaching of innovation and entrepreneurship courses in China should also be taught more by entrepreneurs or 
managers with rich entrepreneurial experience. They often have not only entrepreneurial theoretical knowledge, but also rich entrepreneurial experience, which is more practical for students. And it can stimulate students' interest even more.

Third, actively carry out innovation and entrepreneurship experience exchange activities. Chinese colleges and universities should use campus platforms to frequently hold special lectures on innovation and entrepreneurship, and invite social entrepreneurs, successful entrepreneurs and venture investors to come to the school for exchanges, so as to stimulate students' interest in entrepreneurship and at the same time provide potential financial support for start-ups, which is conducive to innovation. The development of entrepreneurship.

Fourth, meet market demand and explore the direction of innovation. The main purpose of innovation and entrepreneurship is to promote economic development, so the achievements of innovation and entrepreneurship must be meaningful only when the market needs them. Just like Israel's Bureau of Innovation and Entrepreneurship (NATI), China should also set up similar institutions to adapt the innovation ecosystem to the dynamic needs of the market while promoting the transformation of innovation results.

\section{REFERENCES}

[1] Kexia Gu. Innovation and Entrepreneurship Education of Israel Institute of Technology and Its Enlightenment[J].China Higher Education, 2021(06): 62-64.
[2] Xiaohua Su, Yuhan $\mathrm{Wu}$ and Chongyao Gao. Enlightenment of the Israeli Entrepreneurship Education Ecosystem on the Transformation of Scientific and Technological Achievements in Chinese Colleges and Universities. Business Culture, 2021(08): 118-119.

[3] Zhiqiang Wang and Liyu Zhu. The Construction of Innovation and Entrepreneurship Education Ecosystem in Israel and Its Enlightenment----Take Israel Institute of Technology for Example[J].Journal of Hebei Normal University (Education Science), 2020, 22 (01): 67-74.

[4] Zhiqiang Wang and Yiping Dai. The Characteristics and Successful Experience of the Israel Innovation and Entrepreneurship Education Ecosystem[J]. Renmin University of China Education Journal, 2019(01): 105-118.

[5] Jianhua Zhao and Gangzheng She. Israel Innovation and Entrepreneurship Education: the System, Path and Characteristics[J]. Journal of Innovation and Entrepreneurship Education, 2018, 9(06): 83-88.

[6] Wenzhong Fan and Teli Zhou. Israel's Science and Technology Innovation Support Policy[J]. China Finance, 2015(16): 66-68.

[7] ZhiZeng. The Construction and Enlightenment of the Entrepreneurship Environment for Israeli University Students[J].Education Review, 2017(05): 72-76. 